Article

\title{
Anti-Inflammatory and Antibacterial Activity Constituents from the Stem of Cinnamomum validinerve
}

\author{
Chi-Lung Yang ${ }^{1,+}$, Ho-Cheng $\mathrm{Wu}^{2,+}$, Tsong-Long Hwang ${ }^{3,4,5}{ }^{-}$, Chu-Hung Lin ${ }^{1}$,

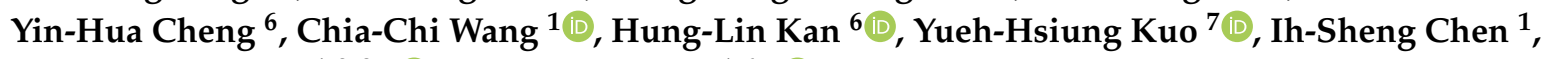
Hsun-Shuo Chang $1,2,8, *(1)$ and Ying-Chi Lin $1,6, *(\mathbb{D})$

1 School of Pharmacy, College of Pharmacy, Kaohsiung Medical University, Kaohsiung 807, Taiwan; long902001@yahoo.com.tw (C.-L.Y.); chuhung.lin@gmail.com (C.-H.L.); ccwang@ntu.edu.tw (C.-C.W.); m635013@kmu.edu.tw (I.-S.C.)

2 Graduate Institute of Natural Products, College of Pharmacy, Kaohsiung Medical University, Kaohsiung 807, Taiwan; duncanwu762001@gmail.com

3 Graduate Institute of Natural Products, College of Medicine, Chang Gung University, Taoyuan 333, Taiwan; htl@mail.cgu.edu.tw

4 Research Center for Industry of Human Ecology, Research Center for Chinese Herbal Medicine, and Graduate Institute of Health Industry Technology, College of Human Ecology, Chang Gung University of Science and Technology, Taoyuan 333, Taiwan

5 Department of Anesthesiology, Chang Gung Memorial Hospital, Taoyuan 333, Taiwan

6 PhD Program in Toxicology, College of Pharmacy, Kaohsiung Medical University, Kaohsiung 807, Taiwan; justjudykimo@gmail.com (Y.-H.C.); k38628511@gmail.com (H.-L.K.)

7 Department of Chinese Pharmaceutical Sciences and Chinese Medicine Resources, Chinese Medicine Research Center, and Research Center for Chinese Herbal Medicine, China Medical University, Taichung 404, Taiwan; kuoyh@mail.cmu.edu.tw

8 Drug Development and Value Creation Research Center, Kaohsiung Medical University, Kaohsiung 807, Taiwan

* Correspondence: hschang@kmu.edu.tw (H.-S.C.); yclin@kmu.edu.tw (Y.-C.L.); Tel.: +886-7-312-1101 (ext. 2664) (H.-S.C.); +886-7-312-1101 (ext. 2012) (Y.-C.L.)

+ These authors contributed equally to this work.

Received: 20 June 2020; Accepted: 23 July 2020; Published: 25 July 2020

\begin{abstract}
One new dibenzocycloheptene, validinol (1), and one butanolide firstly isolated from the natural source, validinolide (2), together with 17 known compounds were isolated from the stem of Cinnamomum validinerve. Among the isolates, lincomolide A (3), secosubamolide (7), and cinnamtannin B1 (19) exhibited potent inhibition on both superoxide anion generation $\left(\mathrm{IC}_{50}\right.$ values of $2.98 \pm 0.3 \mu \mathrm{M}, 4.37 \pm 0.38 \mu \mathrm{M}$, and $2.20 \pm 0.3 \mu \mathrm{M}$, respectively) and elastase release ( $\mathrm{IC}_{50}$ values of $3.96 \pm 0.31 \mu \mathrm{M}, 3.04 \pm 0.23 \mu \mathrm{M}$, and $4.64 \pm 0.71 \mu \mathrm{M}$, respectively) by human neutrophils. In addition, isophilippinolide A (6), secosubamolide (7), and cinnamtannin B1 (19) showed bacteriostatic effects against Propionibacterium acnes in in vitro study, with minimal inhibitory concentration (MIC) values at $16 \mu \mathrm{g} / \mathrm{mL}, 16 \mu \mathrm{g} / \mathrm{mL}$, and $500 \mu \mathrm{g} / \mathrm{mL}$, respectively. Further investigations using the in vivo ear $P$. acnes infection model showed that the intraperitoneal administration of the major component cinnamtannin B1 (19) reduced immune cell infiltration and pro-inflammatory cytokines TNF- $\alpha$ and IL-6 at the infection sites. The results demonstrated the potential of cinnamtannin B1 (19) for acne therapy. In summary, these results demonstrated the anti-inflammatory potentials of Formosan C. validinerve during bacterial infections.
\end{abstract}

Keywords: Cinnamomum validinerve; Lauraceae; anti-inflammatory activity; anti-acne activity 


\section{Introduction}

Lauraceous plants are distributed throughout the tropical and subtropical regions with numerous species. In Taiwan, Lauraceous plants are the main composition of forest and occupy an important position in natural resources. Besides, Lauraceous plants reveal diverse bioactivities, such as anti-tuberculosis, anti-inflammatory, cytotoxicity, and antiplatelet [1], which have garnered worldwide attention. However, still, many Lauraceous plants have never been studied before, and the purpose of this study is to explore the bioactive compounds and potential medication use from Lauraceous plants. Cinnamomum species is one of the famous Lauraceous plants that has economic importance, aromatic potential, and bioactive properties [2]. Especially, cinnamon extracts from Cinnamomum species showed potent anti-acne activity for skincare [3-6]. Cinnamomum validinerve Hance (C. brevipedunculatum C. E. Chang) is a Lauraceous plant growing in Taiwan, Hong Kong, and China [7,8], whose chemical constituents and biological activities have not been investigated before. Recently, we accomplished a series of bioactive screening of Lauraceous plants. The methanolic extract of the stem of $C$. validinerve showed anti-inflammatory and antioxidant activities, indicating its development potential. Therefore, we paid much attention to searching for additional compounds with novel structures and potent bioactivities from C. validinerve.

Neutrophils are famous for playing a significant role in acute inflammatory responses against infections and are also associated with chronic inflammatory and autoimmune diseases [9-11]. Neutrophils infiltrate to the inflamed site, generating superoxide anion and associated reactive oxygen species that exaggerate the inflammatory response further [12]. Bacterial $N$-formyl peptides formyl-L-methionyl-L-leucyl-L-phenylalanine (fMLP) are involved in the innate immunity mechanism of the host defense against pathogens and shown to be chemoattractants for neutrophils. Neutrophils release superoxide anion and elastase in response to fMLP stimulation to initiate the inflammation activity [12].

Acne vulgaris is one of the top three most prevalent skin conditions, which affects $85 \%$ of young adults aged 12-25 years, according to the Global Burden of Disease (GBD) study [13]. It is a chronic inflammatory disease, and the pathogenesis is multifactorial with four primary factors: excess sebum production, abnormal keratinization, inflammation, and bacterial colonization of Propionibacterium acnes in the pilosebaceous unit $[14,15]$. Although not fatal, persistent acne lesions or inflammation on the face could result in serious psychosocial stress to the patients [16]. Topical benzoyl peroxide (BPO) is an established treatment for acne, which helps reduce the chronic use of antibiotics and associated drug-resistant problems. However, BPO may adversely cause skin reactions such as local irritation, reddish skin, or hair bleaching at the start of treatment [17]. Intralesional corticosteroid injection is another option for acne, but it may cause some side effects such as the pitting and thinning of the skin. Thus, more treatment options for possessing anti-acne activity are needed.

Herein, we report the structure elucidation of a new dibenzocycloheptene, validinol (1), a butanolide first isolated from the natural source, and validinolide (2), together with 17 known compounds (Figure 1) from the stem of C. validinerve. The phytochemical spectra of compounds $\mathbf{1}$ and $\mathbf{2}$ are available in the Supplementary Materials. Some compounds were evaluated for anti-inflammatory activity and anti-acne activity in vitro, and the major component, cinnamtannin B1 (19), was further evaluated as the acne treatment in vivo. 


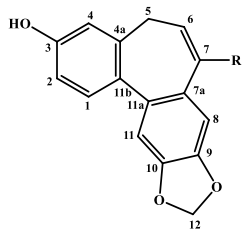<smiles>COc1cc2c(cc1O)C(CO)=CCc1cc(O)ccc1-2</smiles><smiles>CC(C)=C1C(=O)OC(C)C1C</smiles><smiles>C=C1C(=O)C(I)=C(C)C1[18OH]</smiles><smiles>C=C1OC(=O)C(=C(C)C)[C@@H]1C</smiles>
$\begin{aligned} 1, \mathrm{R} & =\mathrm{CH}_{2} \mathrm{OCH}_{3} \\ \mathbf{8}, \mathrm{R} & =\mathrm{CH}_{2} \mathrm{OH}\end{aligned}$<smiles>CCOc1cc(OC)cc2c1C[C@H](C)[C@H](c1ccc3c(c1)OCO3)O2</smiles>

10<smiles>C=C1OC(=O)C(=C(C)C)[C@@H]1C</smiles>

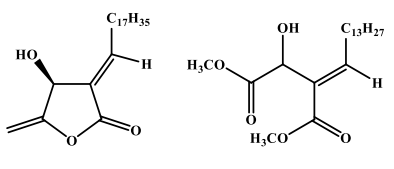

5

6 7<smiles>Oc1cc(O)c2c(c1)O[C@H](c1ccc(O)c(O)c1)[C@H](O)C2</smiles>

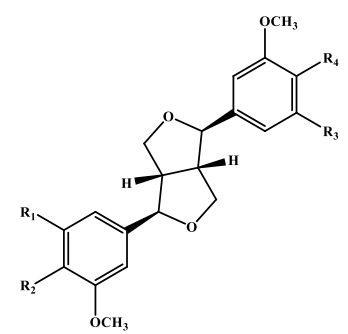

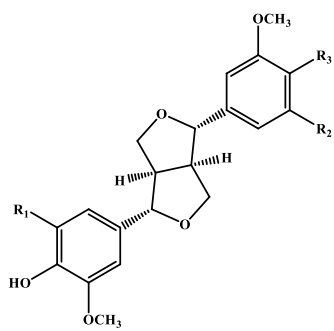

$12, R_{1}=R_{2}=R_{3}=R_{4}=O C H_{3}$

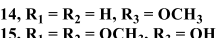<smiles>COC1=C(O[C@H](CO)[C@@H](C)c2ccc(O)c(OC)c2)C(CO)C2COC3=CC(=C1)[C@H]3OCC2Cc1ccc(O)c(OC)c1</smiles>

16

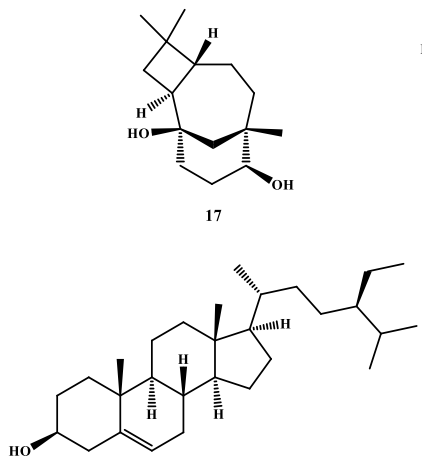

18

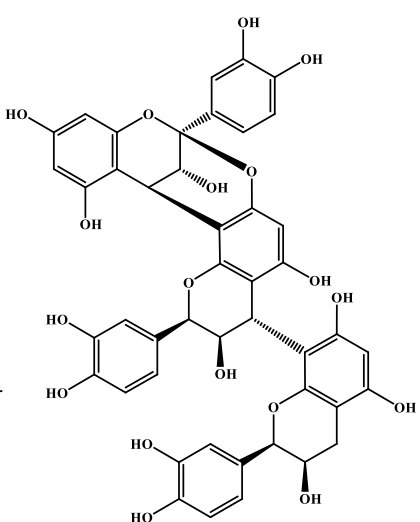

19

Figure 1. Structures of compounds 1-19.

\section{Results}

Validinol (1) was obtained as a pale yellowish oil. The molecular formula was established as $\mathrm{C}_{18} \mathrm{H}_{16} \mathrm{O}_{4}$ by HRESIMS at $m / z 319.09420[\mathrm{M}+\mathrm{Na}]^{+}$(calculated for $\mathrm{C}_{18} \mathrm{H}_{16} \mathrm{O}_{4} \mathrm{Na}$, 319.09408) with 11 degrees of unsaturation. The UV spectrum showed maximum absorption at 245 and $284 \mathrm{~nm}$, and it showed a bathochromic shift after the addition of $\mathrm{KOH}$ solution, suggesting the presence of a phenolic moiety. The UV spectrum of 1 depicted typical $5 H$-dibenzo[ $a, c]$ cycloheptene derivatives [18]. The IR absorption represents the existence of hydroxyl $\left(3301 \mathrm{~cm}^{-1}\right)$, aromatic ring $\left(1604,1501 \mathrm{~cm}^{-1}\right)$, and methylenedioxy $\left(1035,927 \mathrm{~cm}^{-1}\right)$, respectively. The ${ }^{1} \mathrm{H}$ NMR spectrum of 1 showed an $A B X$ aromatic ring at $\delta 6.68(1 \mathrm{H}, \mathrm{d}, J=2.8 \mathrm{~Hz}, \mathrm{H}-4), 6.72(1 \mathrm{H}, \mathrm{dd}, J=8.2,2.8 \mathrm{~Hz}, \mathrm{H}-2)$, and $7.32(1 \mathrm{H}, \mathrm{d}$, $J=8.2 \mathrm{~Hz}, \mathrm{H}-1)$, two singlet aromatic signals at $\delta 7.05(1 \mathrm{H}, \mathrm{s}, \mathrm{H}-11)$ and $7.16(1 \mathrm{H}, \mathrm{s}, \mathrm{H}-8)$, one olefinic proton at $\delta 6.15(1 \mathrm{H}, \mathrm{dd}, J=7.9,7.1 \mathrm{~Hz}, \mathrm{H}-6)$, one methylene at $\delta 2.75(1 \mathrm{H}, \mathrm{dd}, J=12.8,7.1 \mathrm{~Hz}, \mathrm{H}-5 \mathrm{~b})$ and $3.04(1 \mathrm{H}, \mathrm{dd}, J=12.8,7.9 \mathrm{~Hz}, \mathrm{H}-5 \mathrm{a})$, one oxygenated methylene at $\delta 4.04(1 \mathrm{H}, \mathrm{d}, J=11.6 \mathrm{~Hz}$, $\mathrm{H}-13 \mathrm{~b})$ and $4.28(1 \mathrm{H}, \mathrm{br} \mathrm{d}, J=11.6 \mathrm{~Hz}, \mathrm{H}-13 \mathrm{a})$, one methoxy signal at $\delta 3.19(3 \mathrm{H}, \mathrm{s}, \mathrm{H}-14)$, one hydroxyl group at $4.97(1 \mathrm{H}, \mathrm{br} \mathrm{s}, \mathrm{OH}-3)$, and one methylenedioxy proton at $\delta 6.01(1 \mathrm{H}, \mathrm{d}, J=1.2 \mathrm{~Hz}, \mathrm{H}-12 \mathrm{~b})$ 
and $6.02(1 \mathrm{H}, \mathrm{d}, J=1.2 \mathrm{~Hz}, \mathrm{H}-12 \mathrm{a})$. The ${ }^{13} \mathrm{C}$ NMR and DEPT spectra of 1 showed 18 resonances comprising one methyl (C-14), three methylenes $(C-5,12,13)$, six methines $(C-1,2,4,6,8,11)$, and eight quaternary carbons (C-3, 4a, 7, 7a, 9, 10, 11a, 11b). The coupling pattern between H-5 and H-6 and the COSY correlation (Figure 2) represents the existence of a prop-1-ene fragment, which was located at cycloheptene due to the HMBC correlation from H-5 to C-4, as well as C-4a, C-6, C-7, C-11b, and H-6 to C-7a. The methylenedioxy was attached to C-9 and C-10 based on the HMBC correlation between $\mathrm{H}-12$ to $\mathrm{C}-9$ and C-10. The HMBC correlations (Figure 2) were between $\mathrm{OCH}_{3}-14$ to $\mathrm{C}-13$ and $\mathrm{H}-13$ to C-6, C-7, and C-7a, suggesting that the $\mathrm{CH}_{2} \mathrm{OCH}_{3}$ fragment was bearing on C-7. Finally, the remaining $\mathrm{OH}$ is located at the $A B X$ system aromatic ring on C-3. Thus, the entire structure of $\mathbf{1}$ was confirmed and named validinol.

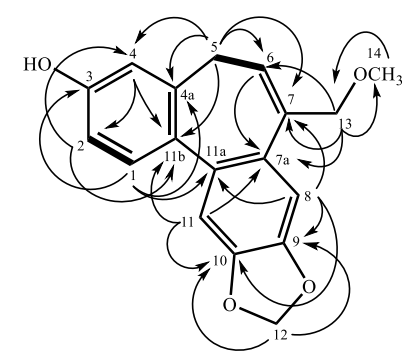

Figure 2. COSY (-) and $\operatorname{HMBC}(\rightarrow)$ correlations of $\mathbf{1}$.

Validinolide (2) was isolated as a colorless oil with a negative specific rotation $[\alpha]_{\mathrm{D}}{ }^{22}-22(c 0.09$, $\mathrm{CHCl}_{3}$ ), and displayed a pseudo-molecular ion at $m / z 305.20882[\mathrm{M}+\mathrm{Na}]^{+}$(calcd. for $\mathrm{C}_{17} \mathrm{H}_{30} \mathrm{O}_{3} \mathrm{Na}_{\text {, }}$ 305.20872) by HRESIMS. The UV spectrum exhibited bands at 217 and $257 \mathrm{~nm}$, indicating the presence of a butyrolactone moiety $[19,20]$. The IR spectrum showed the absorptions at $3387 \mathrm{~cm}^{-1}$ (hydroxyl group), $1727 \mathrm{~cm}^{-1}$, and $1692 \mathrm{~cm}^{-1}\left(\alpha, \beta\right.$-unsaturated- $\gamma$-lactone). In the ${ }^{1} \mathrm{H} \mathrm{NMR}$ spectrum, $2 \mathrm{had}$ the trisubstituted double bond with the Z-form geometry $[\delta 6.56(1 \mathrm{H}, \mathrm{td}, J=7.6,1.2 \mathrm{~Hz}, \mathrm{H}-6)]$. According to the above data, 2 showed the same planer structure of litsenolide C2 [20] except for the configuration. The laevorotatory optical activity suggested that the configuration of 2 could be $(3 S, 4 S)$ or $(3 S, 4 R)[19,21-23]$. Besides, the chemical shifts and coupling patterns of $\mathrm{H}-3$ [ $\delta 4.67(1 \mathrm{H}$, br d, $J=4.9 \mathrm{~Hz})]$ and $\mathrm{H}-4[\delta 4.55(1 \mathrm{H}, \mathrm{qd}, J=6.3,4.9 \mathrm{~Hz}, \mathrm{H}-4)]$ in 2 indicated that $\mathrm{H}-3$ and $\mathrm{H}-4$ are cis-oriented, which is similar to isodihydromahubynolide B [20]. As a consequence, the absolute configurations of C-3 and C-4 were deduced to be $3 S, 4 S$. Based on this information, the structure of 2 was proposed to be (2Z,3S,4S)-2-(dodecylidene)-3-hydroxy-4-methylbutanolide and named validinolide, which was first isolated from nature. It has been previously synthesized and yielded as a mixture [19,20].

The known compounds lincomolide A (3) [24], linderanolide B (4) [25], isolinderanolide B (5) [25], isophilippinolide A (6) [26], secosubamolide (7) [27], reticuol (8) [28], burmanol (9) [29], (-)-5,7-dimethoxy-3', 4' -methylenedioxy-flavan-3-ol (10) [30], taxifolin (11) [31], (-)-yangambin (12) [32], (-)-pinoresinol (13) [33], (+)-monomethylpinoresinol (14) [34], (+)-syringaresinol (15) [33], erythro-guaiacylglycerol- $\beta-O-4^{\prime}-\left(5^{\prime}\right)$-methoxylariciresinol (16) [35], caryolane-1,9 $\beta$-diol (17) [36], $\beta$-sitosterol (18) [37], and cinnamtannin B1 (19) [38] were identified by comparisons of physical and spectroscopic data $\left([\alpha]_{\mathrm{D}}, \mathrm{UV}, \mathrm{IR},{ }^{1} \mathrm{H} \mathrm{NMR}\right.$, and MS) with authentic samples or literature data. Among them, cinnamtannin B1 (19) (3.6 g) was obtained as the major constituent.

In this study, the effects of isolates on neutrophil pro-inflammatory responses were evaluated by the suppression of $\mathrm{fMLP} / \mathrm{CB}$ (cytochalasin $\mathrm{B}$ )-induced superoxide anion $\left(\mathrm{O}^{2-}\right)$ generation and

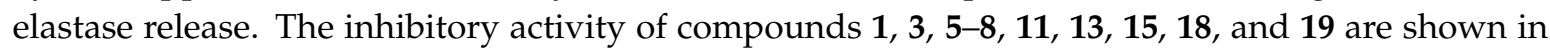
Table 1. Compounds 3, 7, and 19 exhibited inhibitory activities on both superoxide anion (IC 50 values of $2.98 \pm 0.3 \mu \mathrm{M}, 4.37 \pm 0.38 \mu \mathrm{M}$, and $2.20 \pm 0.3 \mu \mathrm{M})$ and elastase release $\left(\mathrm{IC}_{50}\right.$ values of $3.96 \pm 0.31 \mu \mathrm{M}$, $3.04 \pm 0.23 \mu \mathrm{M}$, and $4.64 \pm 0.71 \mu \mathrm{M}$ ), and compound 13 only showed inhibitory activity on superoxide anion with an $\mathrm{IC}_{50}$ value of $5.99 \pm 1.77 \mu \mathrm{M}$. 
Table 1. Effect of compounds on superoxide anion generation and elastase release in $N$-formyl peptides formyl-1-methionyl-1-leucyl-1-phenylalanine (fMLP)/CB-stimulated human neutrophils.

\begin{tabular}{|c|c|c|c|c|}
\hline \multirow{2}{*}{ Compound } & \multicolumn{2}{|c|}{ Superoxide Anion } & \multicolumn{2}{|c|}{ Elastase Release } \\
\hline & $\mathrm{IC}_{50}(\mu \mathrm{M})^{\mathrm{a}}$ & Inhibition ${ }^{b}(\%)$ & $\mathrm{IC}_{50}(\mu \mathrm{M})$ & Inhibition (\%) \\
\hline validinol (1) & $>10$ & $17.16 \pm 3.69 *$ & $>10$ & $17.34 \pm 6.84$ * \\
\hline lincomolide A (3) & $2.98 \pm 0.30$ & $93.27 \pm 2.66 *$ & $3.96 \pm 0.31$ & $66.89 \pm 6.72 *$ \\
\hline isolinderanolide B (5) & $>10$ & $11.58 \pm 2.43 *$ & $>10$ & $23.16 \pm 5.04 *$ \\
\hline isophilippinolide A (6) & $>10$ & $4.94 \pm 7.00$ & $>10$ & $14.36 \pm 3.10 *$ \\
\hline secosubamolide $(7)$ & $4.37 \pm 0.38$ & $80.25 \pm 5.45 *$ & $3.04 \pm 0.23$ & $101.07 \pm 6.68 *$ \\
\hline reticuol (8) & $>10$ & $-0.91 \pm 0.30 *$ & $>10$ & $-17.28 \pm 6.65$ * \\
\hline taxifolin (11) & $>10$ & $30.04 \pm 4.30 *$ & $>10$ & $17.09 \pm 2.63$ \\
\hline (-)-pinoresinol (13) & $5.99 \pm 1.77$ & $65.61 \pm 7.51 *$ & $>10$ & $20.64 \pm 3.41 *$ \\
\hline (+)-syringaresinol (15) & $>10$ & $2.91 \pm 0.92 *$ & $>10$ & $2.16 \pm 4.41$ \\
\hline$\beta$-sitosterol (18) & $>10$ & $11.80 \pm 6.57$ & $>10$ & $-6.48 \pm 4.17$ \\
\hline cinnamtannin B1 (19) & $2.20 \pm 0.30$ & $91.58 \pm 4.04 *$ & $4.64 \pm 0.71$ & $71.27 \pm 5.08 *$ \\
\hline LY294002 c & $2.17 \pm 0.53$ & & $6.38 \pm 1.72$ & \\
\hline
\end{tabular}

${ }^{\mathrm{a}}$ Concentration necessary for $50 \%$ inhibition. ${ }^{\mathrm{b}}$ Inhibition percentage examined at samples concentration of $10 \mu \mathrm{M}$.

The data represent the mean \pm SEM. $(\mathrm{n}=3$ or 4$) .{ }^{*} p<0.05$ compared with the control. ${ }^{c}$ positive control.

Compounds 6, 7, and 19 were evaluated for their ability to inhibit the growth of Propionibacterium acnes. Compounds 6 and 7 showed anti-microbial activity against $P$. acnes, with a minimal inhibitory concentration (MIC) value of $16 \mu \mathrm{g} / \mathrm{mL}$. Compound 19 only exhibited moderate anti-microbial activity against $P$. acnes with an MIC value of $500 \mu \mathrm{g} / \mathrm{mL}$. The MIC of benzoyl peroxide, the active component of epicutaneous medications for acne treatment, as a positive control in our experiment was $1000 \mu \mathrm{g} / \mathrm{mL}$.

As cinnamtannin B1 (19) is the major component in the stem of $C$. validinerve and showed anti-inflammatory and anti-P. acnes activities in vitro, we further examined the potential of cinnamtannin B1 (19) as an acne treatment with an in vivo P. acnes ear infection model. At the dosage of $20 \mathrm{mg} / \mathrm{kg}$ administered intraperitoneally, cinnamtannin B1 (19) was able to reduce the redness of the ears starting from $24 \mathrm{~h}$ (Figure 3A,B). Furthermore, cinnamtannin B1 (19) decreased immune cell infiltration in the mouse ears infected with P. acnes (Figure 3C,D) and trended to decrease the inflammatory cytokines TNF- $\alpha(p=0.098)$ and IL-6 levels $(p=0.377)$ associated with the infection (Figure 4$)$. No significant decrease in bacterial load was observed $\left(1.08 \times 10^{6} \mathrm{CFU} / \mathrm{mL}\right.$ versus $3.10 \times 10^{6} \mathrm{CFU} / \mathrm{mL}$ in treated versus control ears).

(A)

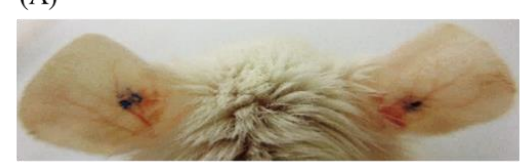

(C)

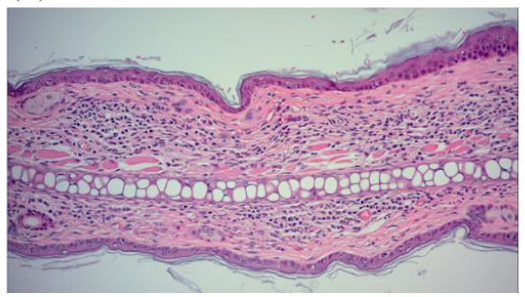

(B)

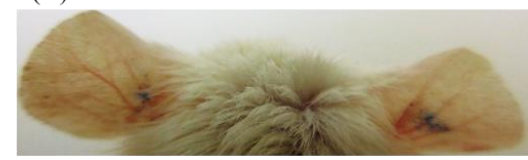

(D)

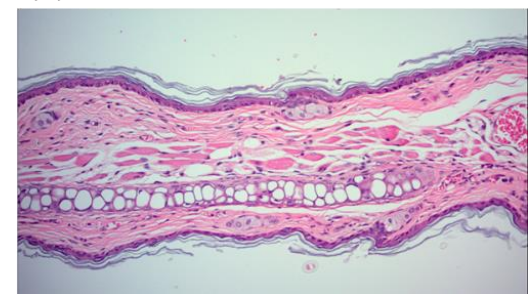

Figure 3. In vivo anti-inflammatory activity of cinnamtannin B1 (19). P. acnes was intradermally injected into the ears at the blue-marked positions, and phosphate-buffered solution (PBS) or 19 (20 mg/kg) were administered intraperitoneally daily for 4 days starting right after the infection. Representative photos of mice (A) PBS-treated and (B) 19-treated $24 \mathrm{~h}$ after the infection. (C) A PBS-treated histology section (H\&E staining) (D) a 19-treated histology section (H\&E staining) on day 5 after the infection. The sections were $200 \times$-magnified. 


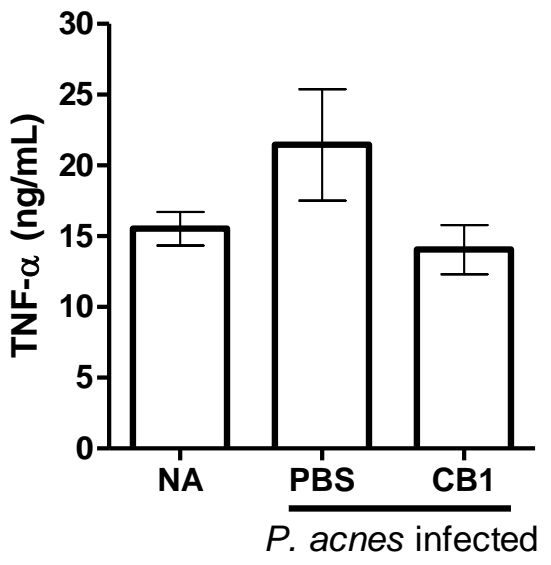

(A)

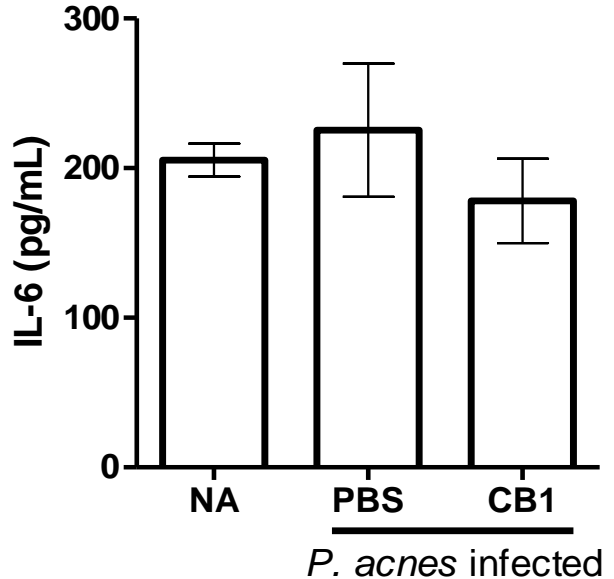

(B)

Figure 4. Anti-inflammatory effect of compound 19 in P. acnes ear infection model. (A) TNF- $\alpha$, (B) IL-6. The data were pooled from two independent experiments. Error bar indicated the standard deviation of the mean (SEM). Control: naïve mice ( $\mathrm{N}=2)$; PBS: P. acnes infected, PBS-treated mice $(\mathrm{N}=6)$; CB1: P. acnes infected, $19(20 \mathrm{mg} / \mathrm{kg})$-treated mice $(\mathrm{N}=7)$. $p$-value between PBS and CB1 for TNF- $\alpha$ and IL-6 were 0.098 and 0.377 , respectively.

\section{Discussion}

Inflammation is a part of the innate immune mechanism to defense infection or tissue injury. However, prolonged, dysregulated, or excessive inflammation could adversely cause tissue destruction and human diseases. Traditionally, Cinnamomum is used for flavoring food and pharmaceutical medications around the world. Although some studies reported the anti-inflammatory activity from Cinnamomum, this is the first time evaluating the inhibition effects of Cinnamomum compounds on superoxide anion and elastase release in $\mathrm{AMLP} / \mathrm{CB}$-activated human neutrophils. Focusing on the anti-inflammatory activity results in this paper, compounds 3, 7, and 19 exhibited inhibitory activities on superoxide anion and elastase release. The results in chemistry also contributed to the chemotaxonomy of Cinnamomum species. According to the in vitro anti-microbial activities against $P$. acnes, cinnamtannin B1 (19) was better than BPO in its antibacterial activity against P. acnes. Cinnamtannin B1 (19) also showed good anti-inflammatory activity in vivo, which was shown to relieve the inflammation associated with $P$. acne infections. By contrast, BPO was too irritating to be administered systematically. Therefore, cinnamtannin B1 (19) has the potential to be further evaluated for anti-acne therapy in humans, especially if topical formulations can be developed. The combination of cinnamtannin B1 (19) with other currently available treatments for acne may also be worthy of further evaluation to decrease the use of antibiotics in the treatment of the chronic condition and/or to potentiate anti-acne treatment effects for other agents with different mechanisms of action [39].

Three compounds, namely isophilippinolide A (6), secosubamolide (7), and cinnamtannin B1 (19), were reported with anti-P. acnes activities. Although the tannin compound "cinnamtannin B1 (19)" was not the compound with the best anti-inflammatory activity nor anti-P. acnes activity, the abundance of the compound in this plant enables us to perform a pilot study $P$. acnes infection experiment in vivo. It is worth mentioning that a reduction in the P. acnes-induced redness can be observed from $24 \mathrm{~h}$ after the infection, and reduced immune cell infiltration and pro-inflammation cytokines, TNF- $\alpha$ and IL-6, were maintained and observed on day 5 . The mouse-ear infection model was chosen because its confined region can preserve all inoculated bacteria in the injection area. However, given that cinnamtannin B1 (19) was administered intraperitoneally, the concentration of cinnamtannin B1 (19) at the ears may be too low to reduce the bacterial load at the infection sites. The reduction in the signs 
and symptoms of inflammation was likely due to the anti-inflammatory activity of cinnamtannin B1 (19). The observations implied that cinnamtannin B1 may achieve better anti-acne property if the dose or administration method can be further optimized.

\section{Conclusions}

One new dibenzocycloheptene, validinol (1), and one butanolide firstly isolated from the natural source, validinolide (2), together with 17 known compounds, were obtained from the stem of C. validinerve. Six butanolides are successfully isolated from $C$. validinerve, which were the most major skeleton in this study. These phytochemical results fitted with the previous investigation that butanolides are abundant in Cinnamomum genus [1]. This result also contributed to the chemotaxonomy of Cinnamomum genus. For the treatment of acne vulgaris, we targeted two main pathogenesis factors, inflammation and P. acne, for the treatment of acne vulgaris. This report also demonstrated that C. validinerve contains some butanolide and tannin compounds with anti-inflammatory activity and anti-acne activity, which is helpful to patients with inflammation-related disease.

\section{Materials and Methods}

\subsection{General Experimental Procedures}

All melting points were determined on a Yanaco micromelting apparatus (Yanaco, Kyoto, Japan) and were uncorrected. Optical rotations were measured on a Jasco P-2000 polarimeter (Jasco, Kyoto, Japan), UV spectra were obtained with a Jasco-V-530 UV/vis spectrophotometer (Jasco, Kyoto, Japan), and IR spectra (ATR) were acquired with a Jasco FT/IR-4600 spectrometer. $1 \mathrm{D}\left({ }^{1} \mathrm{H},{ }^{13} \mathrm{C}, \mathrm{DEPT}\right)$ and 2D (COSY, NOESY, ROESY, HSQC, HMBC) NMR spectra were recorded on a Varian Germini-2000 spectrometer (Varian, Inc. Vacuum Technologies, MA, USA) operated at $200 \mathrm{MHz}\left({ }^{1} \mathrm{H}\right)$ and $50 \mathrm{MHz}$ $\left({ }^{13} \mathrm{C}\right)$, a Varian Unityplus-400 spectrometer (Varian, Inc. Vacuum Technologies, MA, USA) operated at $400 \mathrm{MHz}\left({ }^{1} \mathrm{H}\right)$ and $100 \mathrm{MHz}\left({ }^{13} \mathrm{C}\right)$, a Varian Mercuryplus-400 spectrometer (Varian, Inc. Vacuum Technologies, MA, USA) operated at $400 \mathrm{MHz}\left({ }^{1} \mathrm{H}\right)$ and $100 \mathrm{MHz}\left({ }^{13} \mathrm{C}\right)$, and a Varian VNMRS-600 spectrometer (Varian, Inc. Vacuum Technologies, Lexington, MA, USA) operated at $600 \mathrm{MHz}\left({ }^{1} \mathrm{H}\right)$ and $150 \mathrm{MHz}\left({ }^{13} \mathrm{C}\right)$. Low-resolution mass spectra were obtained with POLARIS Q Thermo Finnigan (Thermo Fisher Scientific, Chicago, IL, USA), Water ZQ 4000 (Waters, Milford, MA, USA), and VG Quattro GC/MS/MS/DS (Waters, Milford, MA, USA) mass spectrometers. HRESIMS were recorded on a Bruker APEX II mass spectrometer (Bruker, Karlsruhe, Germany). Silica gel (70-230 and 230-400 mesh; Silicycle, Quebec, Canada) was used for column chromatography (CC), and silica gel 60 F254 (Merck, Darmstadt, Germany) and RP-18 F254S (Merck, Darmstadt, Germany) were used for thin-layer chromatography (TLC) and preparative TLC, respectively, which were visualized with $\mathrm{Ce}_{2}(\mathrm{SO} 4)_{3}$ aqueous solution. Further purification was performed by medium-performance liquid chromatography (MPLC; ceramic pump: VSP-3050; EYELA, Kyoto, Japan).

\subsection{Plant Material}

The stem of C. validinerve was collected from Mudan, Pingtung County, Taiwan, in January 2013 and identified by I.-S. C. A voucher specimen (Chen 2321) was deposited in the School of Pharmacy, Kaohsiung Medical University, Kaohsiung, Taiwan.

\subsection{Extraction and Isolation}

The dried stem $(6.5 \mathrm{~kg})$ were extracted with $\mathrm{MeOH}$, obtaining a $\mathrm{MeOH}$ extract $(350 \mathrm{~g})$. The $\mathrm{MeOH}$ extract was partitioned into an ethyl acetate-soluble fraction (200 g) and $\mathrm{H}_{2} \mathrm{O}$-soluble fraction (120 g). The active ethyl acetate-soluble fraction (100 g) was chromatographed over silica gel using an n-hexane-acetone gradient to yield 15 fractions (Fraction 1-Fraction 15). Fraction 2 (9.2 g) was chromatographed by silica gel eluting with $n$-hexane-acetone gradient to give 37 fractions. Fraction 2-20 was purified via a silica gel column using $n$-hexane-ethyl acetate (10:1) to afford 6 (12.6 mg) 
and $7(9.8 \mathrm{mg})$. Fraction 3 was submitted to silica gel column eluting with $n$-hexane-ethyl acetate $(10: 1)$ to give 17 fractions and to obtain 5 (44.8 mg). Fraction 3-14 was chromatographed by silica gel eluting with dichloromethane-ethyl acetate (50:1) to give 10 fractions. Fraction 3-14-7 was eluted with $\mathrm{H}_{2} \mathrm{O}$-methanol (1:10) through RP-18 column to afford 18 (15.4 mg). Fraction 4 was submitted to silica gel column eluting with $n$-hexane-ethyl acetate $(7: 1)$ to give 18 fractions. Fraction $4-14$ was purified by preparative RP-18 TLC ( $\mathrm{H}_{2} \mathrm{O}-$ methanol, 1:5) to give 2 (2.5 mg) and 3 (2.7 mg). Fraction 4-4 was purified by preparative RP-18 TLC $\left(\mathrm{H}_{2} \mathrm{O}\right.$-acetone, 1:5) to furnish $4(2.0 \mathrm{mg})$. Fraction 5 was subjected to a silica gel column with $n$-hexane-acetone $(4: 1)$ and was purified by preparative TLC (dichloromethane-acetone, 30:1) to produce $\mathbf{1}(2.3 \mathrm{mg})$ and $10(1.3 \mathrm{mg})$. Fraction 7 was eluted with dichloromethane-methanol (30:1) by silica gel column to gain 14 fractions. Fraction 7-2 was purified on $\mathrm{RP}-18$ silica gel eluting with $\mathrm{H}_{2} \mathrm{O}$-methanol (1:2) to generate 12 (0.6 mg). Both Fraction 7-3 and Fraction 7-6 were purified via an RP-18 column eluting with $\mathrm{H}_{2} \mathrm{O}$-methanol (1:2) to give 14 (0.4 mg) and $9(0.7 \mathrm{mg})$. Fraction 7-12 was purified by an RP-18 column eluting with $\mathrm{H}_{2} \mathrm{O}-$ methanol (1:2) to obtain 17 (1.8 mg). Fraction 8 was chromatographed by RP-18 silica gel eluting with $\mathrm{H}_{2} \mathrm{O}-\mathrm{methanol}$ (1:1) to give 11 fractions. Both Fraction 8-2 and Fraction 8-4 were purified by preparative TLC (dichloromethane-methanol, 30:1) to produce $\mathbf{1 3}(7.0 \mathrm{mg})$ and $\mathbf{8}(2.4 \mathrm{mg})$. Fraction 9 was submitted to a silica gel column eluting with dichloromethane-methanol $(15: 1)$ to give nine fractions. Fraction 9-5 was purified via silica gel eluting with $n$-hexane-acetone (3:2) to give nine fractions. Fraction 9-5-7 was purified by preparative RP-18 TLC $\left(\mathrm{H}_{2} \mathrm{O}-\right.$ methanol, 1:1) to provide 11 (24.3 mg). Fraction 9-3 was purified by RP-18 column eluting with $\mathrm{H}_{2} \mathrm{O}$-acetone (3:2) to obtain 15 (5.4 mg). Fraction 11 went through an RP-18 column eluting with dichloromethane-methanol (20:1) and provided seven fractions. Fraction 11-3 was isolated via an RP-18 column eluting with $\mathrm{H}_{2} \mathrm{O}$-acetonitrile (2:1) and was purified by preparative TLC (n-hexane-acetone-methanol, 1:1:0.1) to furnish 16 (1.9 mg). Fraction 12 was subjected to silica gel column eluting with dichloromethane-methanol (5:1), gradually increasing the polarity with methanol to obtain 19 (3.6 g).

\subsection{Experimental Data of Isolates}

Validinol (1): pale yellowish oil; UV $\lambda_{\max }(\mathrm{MeOH})(\log \varepsilon): 245$ (4.76), 284 (4.59) nm; UV $\lambda_{\max }$ $(\mathrm{MeOH}+\mathrm{KOH})(\log \varepsilon): 252$ (4.79), 298 (4.72) nm; IR $v_{\max }(\mathrm{ATR}): 3301(\mathrm{OH}), 1604,1501$ (aromatic ring), 1035, $927\left(\mathrm{OCH}_{2} \mathrm{O}\right) \mathrm{cm}^{-1}$; ESIMS m/z: $319[\mathrm{M}+\mathrm{Na}]^{+} ; \operatorname{HRESIMS~m/z:~} 319.09420[\mathrm{M}+\mathrm{Na}]^{+}$(calcd. for $\left.\mathrm{C}_{18} \mathrm{H}_{16} \mathrm{O}_{4} \mathrm{Na}, 319.09408\right) .{ }^{1} \mathrm{H} \mathrm{NMR}\left(\mathrm{CDCl}_{3}, 400 \mathrm{MHz}\right) \delta: 2.75(1 \mathrm{H}, \mathrm{dd}, J=12.8,7.1, \mathrm{H}-5 \mathrm{~b}), 3.04(1 \mathrm{H}$, $\mathrm{dd}, J=12.8,7.9, \mathrm{H}-5 \mathrm{a}), 3.19$ (3H, s, H-14), 4.04 (1H, d, $J=11.6, \mathrm{H}-13 \mathrm{~b}), 4.28(1 \mathrm{H}, \mathrm{d}, J=11.6, \mathrm{H}-13 \mathrm{a})$, $4.97\left(1 \mathrm{H}\right.$, br s, OH-3, $\mathrm{D}_{2} \mathrm{O}$ exchangeable), $6.01(1 \mathrm{H}, \mathrm{d}, J=1.2, \mathrm{H}-12 \mathrm{~b}), 6.02(1 \mathrm{H}, \mathrm{d}, J=1.2, \mathrm{H}-12 \mathrm{a})$, $6.15(1 \mathrm{H}, \mathrm{dd}, J=7.9,7.1, \mathrm{H}-6), 6.68(1 \mathrm{H}, \mathrm{d}, J=2.8, \mathrm{H}-4), 6.72(1 \mathrm{H}, \mathrm{dd}, J=8.2,2.8, \mathrm{H}-2), 7.05(1 \mathrm{H}, \mathrm{s}$,

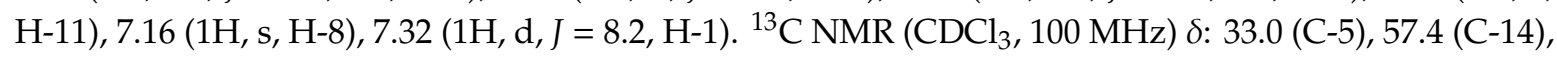
75.9 (C-13), 101.2 (C-12), 106.3 (C-8), 109.4 (C-11), 112.8 (C-4), 113.1 (C-2), 129.8 (C-6), 130.4 (C-7a), 130.7 (C-1), 131.4 (C-11b), 134.30 (C-11a), 134.35 (C-7), 143.7 (C-4a), 146.3 (C-9 and C-10), 155.2 (C-3).

Validinolide (2): colorless oil; $[\alpha]_{\mathrm{D}}^{22}-22.0\left(\right.$ c $\left.0.09 ; \mathrm{CHCl}_{3}\right) ; \mathrm{UV} \lambda_{\max }(\mathrm{MeOH})(\log \varepsilon): 217$ (3.73), 257 (2.92) nm; IR $v_{\max }(\mathrm{ATR}): 3387(\mathrm{OH}), 1727,1692\left(\alpha, \beta\right.$-unsaturated- $\gamma$-lactone) $\mathrm{cm}^{-1}$; ESIMS m/z: $283[\mathrm{M}+\mathrm{H}]^{+}$. HRESIMS m/z: $305.20882[\mathrm{M}+\mathrm{Na}]^{+}$(calcd. for $\left.\mathrm{C}_{17} \mathrm{H}_{30} \mathrm{O}_{3} \mathrm{Na}, 305.20872\right) ;{ }^{1} \mathrm{H} \mathrm{NMR}$ $\left(\mathrm{CDCl}_{3}, 200 \mathrm{MHz}\right) \delta 0.88(3 \mathrm{H}, \mathrm{t}, J=6.4 \mathrm{~Hz}, \mathrm{H}-17), 1.26(16 \mathrm{H}$, br s, H-9-H-16), $1.40(3 \mathrm{H}, \mathrm{d}, J=6.3 \mathrm{~Hz}$, H-5), 1.59 (2H, m, H-8), 2.73 (2H, m, H-7), 4.55 (1H, qd, J = 6.3, 4.9 Hz, H-4), $4.67(1 \mathrm{H}$, br d, J = 4.9 Hz, $\mathrm{H}-3), 6.56(1 \mathrm{H}, \mathrm{td}, J=7.6,1.2 \mathrm{~Hz}, \mathrm{H}-6)$.

\subsection{Superoxide Anion and Elastase Release Assays}

The ability of testing compounds to modulate superoxide anion generation and elastase release by neutrophils was evaluated as those of the references published by co-author Professor Tsong-Long Hwang [40,41]. The superoxide generation assay was based on the reduction of ferricytochrome c by superoxide dismutase (SOD). The elastase release assay was performed by measuring the changes in elastase substrate MeO-Suc-Ala-Ala-Pro-Val- $p$-nitroanilide. Human neutrophils $\left(6 \times 10^{5}\right.$ cells $\left./ \mathrm{mL}\right)$ were 
pre-incubated with ferricytochrome $c(0.5 \mathrm{mg} / \mathrm{mL})$ at $37^{\circ} \mathrm{C}$, and then testing compounds were added for 5 min before activation by fMLF $(0.1 \mu \mathrm{M})$ in the presence of cytochalasin B $(1 \mu \mathrm{g} / \mathrm{mL})$. The absorbance at $550 \mathrm{~nm}$ was monitored continuously using a spectrophotometer. Human neutrophils $\left(6 \times 10^{5} \mathrm{cells} / \mathrm{mL}\right)$ were pre-incubated with elastase substrate (methoxysuccinyl-Ala-Ala-Pro-Val-p-nitroanilide, $100 \mu \mathrm{M}$ ) at $37^{\circ} \mathrm{C}$, and then testing compounds were added for $5 \mathrm{~min}$ before activation by fMLF $(0.1 \mu \mathrm{M})$ in the presence of cytochalasin B $(0.5 \mu \mathrm{g} / \mathrm{mL})$. The absorbance at $405 \mathrm{~nm}$ was monitored continuously using a spectrophotometer. The results are expressed as a percentage of the rate of elastase release in the fMLP/CB-activated under DMSO (solvent, 0.1\%). PI3K inhibitor LY29002 served as positive controls for the neutrophil assays. All assays were repeated three times. Results are presented as mean \pm standard error of the mean (SEM). The student's $t$-test was used to compare the test compound with DMSO control. A probability less than 0.05 was considered significant.

\subsection{Minimum Inhibitory Concentration (MIC)}

The antibacterial activities of the test compounds were evaluated by the broth microdilution method, according to the recommendations by Clinical and Laboratory Standard Institute (CLSI) guidelines. Propionibacterium acnes BCRC10723 (ATCC 6919) was obtained from the Bioresource Collection and Research Center (BCRC, Hsinchu, Taiwan).

Briefly, $P$ acnes was cultured on the anaerobic blood agar plate at $37^{\circ} \mathrm{C}$ for $72 \mathrm{~h}$ under anaerobic conditions. The bacteria were washed and re-suspended to Reinforced Clostridial Medium (RCM). Test compounds were twofold serial diluted in RCM. The inoculum was approximately $5 \times 10^{5}$ Colony forming unit (CFU)/mL. The 96-well MIC plates were incubated at $37^{\circ} \mathrm{C}$ under the anaerobic condition for $72 \mathrm{~h}$. The MICs were defined as the lowest concentrations of the test compounds without visible bacterial growth. All tests were performed in duplicate.

\subsection{Propionibacterium Acnes Mice Infection Model}

A mouse ear infection model was used [17]. Experiments involving animal studies were reviewed, approved, and performed under the regulatory supervision of Kaohsiung Medical University's Institutional Animal Care and Use Committee (IACUC, no. 106015). Briefly, P. acnes was cultured on anaerobic blood agar plate under the anaerobic condition at $37^{\circ} \mathrm{C}$ for three days. The bacteria were taken from the plate and distributed into PBS. The ears of BALB/c mice were injected with about $5 \times 10^{6} \mathrm{CFU}$ of $P$. acnes in 10 or $20 \mu \mathrm{L}$ phosphate-buffered solution (PBS). The ears of mice without bacteria served as background controls (NA). The stock concentration of cinnamtannin B1 (19) was $20 \mathrm{mg} / \mathrm{mL}$ in PBS. Cinnamtannin B1 (19) $(20 \mathrm{mg} / \mathrm{kg})$ was intraperitoneally administered once daily for four days, starting immediately after the infection. In the control group, mice were injected with PBS.

The ears of the mice were collected on Day 5 for bacterial culture, cytokine measurements, and histology. The ears were weighted and homogenized in twofold volume $(\mu \mathrm{L} / \mathrm{mg})$ of PBS on ice. The differences in cytokine levels between cinnamtannin B1 (19)-treated and the control group were analyzed using an unpaired t-test. The skin sections were paraffin-embedded, cut into $3 \mu \mathrm{m}$-thick slides, and hematoxylin and eosin stained.

Supplementary Materials: The following are available online, including the phytochemical spectra of compounds $\mathbf{1}$ and $\mathbf{2}$, and the experimental data of known compounds.

Author Contributions: Conceptualization, I.-S.C., H.-S.C., and Y.-C.L.; methodology, T.-L.H., H.-S.C., H.-C.W., and Y.-C.L; formal analysis, C.-L.Y., H.-C.W., C.-H.L., Y.-H.C., and H.-L.K.; investigation, C.-L.Y., H.-C.W., C.-H.L., Y.-H.C., and H.-L.K.; resources, I.-S.C. and H.-S.C.; data curation, C.-H.L., C.-C.W., H.-S.C., and Y.-C.L.; writing-original draft preparation, C.-L.Y. and H.-C.W.; writing-review and editing, T.-L.W., Y.-H.K., I.-S.C., H.-S.C., and Y.-C.L.; visualization, H.-S.C. and Y.-C.L.; supervision, H.-S.C. and Y.-C.L.; project administration, H.-S.C. and Y.-C.L.; funding acquisition, H.-S.C. and Y.-C.L. All authors have read and agreed to the published version of the manuscript.

Funding: This study was supported by the Ministry of Science and Technology, R.O.C. (MOST 109-2628-B-037-015), and Kaohsiung Medical University's grant (KMU-TC108A03-8, KMU-TC108A03-9, and KMU-M108014) 
Acknowledgments: We thank the Center for Research Resources and Development of Kaohsiung Medical University for providing a nuclear magnetic resonance (NMR) spectrometer, and also senior technician Chyi-Jia Wang for measuring the 2D NMR data.

Conflicts of Interest: The authors declare no conflict of interest.

\section{References}

1. Chang, H.S.; Chen, I.S. Chemical constituents and bioactivity of Formosan lauraceous plants. J. Food Drug Anal. 2016, 24, 247-263. [CrossRef]

2. Kumar, S.; Kumari, R.; Mishra, S. Pharmacological properties and their medicinal uses of Cinnamomum: A review. J. Pharm. Pharmacol. 2019, 71, 1735-1761. [CrossRef]

3. Julianti, E.; Rajah, K.K.; Fidrianny, I. Antibacterial activity of ethanolic extract of Cinnamon bark, honey, and their combination effects against acne-causing bacteria. Sci. Pharm. 2017, 85, 19. [CrossRef] [PubMed]

4. Ghovvati, M.; Afshari, G.K.; Nasrollahi, S.A.; Firooz, A.; Samadi, A.; Karimi, M.; Talebi, Z.; Kolahdooz, S.; Vazirian, M. Efficacy of topical cinnamon gel for the treatment of facial acne vulgaris: A preliminary study. Biomed. Res. Ther. 2019, 6, 2958-2965. [CrossRef]

5. Madhubala, S.; Poongothai, M.; Mahesh, K.E. Antibacterial and anti acne activity of Caesalpinia sappan L. and Cinnamomum verum J. Presl-A comparison. Int. J. Adv. Res. Biol. Sci. 2018, 5, 118-122.

6. Han, X.; Parker, T. Antiinflammatory activity of Cinnamon (Cinnamomum zeylanicum) bark essential oil in a human skin disease model. Phytother. Res. 2017, 31, 1034-1038. [CrossRef]

7. Chang, C.E. A review on the study of Lauraceae of Taiwan. Q. J. Chin. For. 2005, 38, 133-145. [CrossRef]

8. Liao, J.C. Lauraceae in Flora of Taiwan, 2nd ed.; Editorial Committee of the Flora of Taipei: Taipei, Taiwan, 1996; Volume 2, pp. 433-499.

9. Amulic, B.; Cazalet, C.; Hayes, G.L.; Metzler, K.D.; Zychlinsky, A. Neutrophil function: From mechanisms to disease. Annu. Rev. Immunol. 2012, 30, 459-489. [CrossRef]

10. Wright, H.L.; Moots, R.J.; Edwards, S.W. The multifactorial role of neutrophils in rheumatoid arthritis. Nat. Rev. Rheumatol. 2014, 10, 593-601. [CrossRef]

11. Chiang, C.C.; Cheng, W.J.; Korinek, M.; Lin, C.Y.; Hwang, T.L. Neutrophils in psoriasis. Front. Immunol. 2019, 10, 2376. [CrossRef]

12. Le, Y.; Yang, Y.; Cui, Y.; Yazawa, H.; Gong, W.; Qiu, C.; Wang, J.M. Receptors for chemotactic formyl peptides as pharmacological targets. Int. Immunopharmacol. 2002, 2, 1-13. [CrossRef]

13. GBD Compare Data Visualization. Available online: https://vizhub.healthdata.org/gbd-compare/ (accessed on 17 February 2020).

14. Rosen, J.; Friedman, A.J. Inflammatory acne: New developments in pathogenesis and treatment. Cutis 2014, 94, 266-267.

15. Tanghetti, E.A. The role of inflammation in the pathology of acne. J. Clin. Aesthet. Dermatol. 2013, 6, 27-35. [PubMed]

16. Zhu, T.; Wu, W.; Yang, S.; Li, N.; Sun, D.; He, L. Polyphyllin I inhibits Propionibacterium acnes-induced inflammation in vitro. Inflammation 2019, 42, 35-44. [CrossRef] [PubMed]

17. Pornpattananangkul, D.; Fu, V.; Thamphiwatana, S.; Zhang, L.; Chen, M.; Vecchio, J.; Gao, W.; Huang, C.M.; Zhang, L. In vivo treatment of Propionibacterium acnes infection with liposomal lauric acids. Adv. Healthc. Mater. 2013, 2, 1322-1328. [CrossRef]

18. Budac, D.; Wan, P. Excited state carbon acid dissociation and competing photorearrangements of $5 H$-dibenzo[a,c]cycloheptene derivatives. Can. J. Chem. 1996, 74, 1447-1464. [CrossRef]

19. Takeda, K.; Sakurawi, K.; Ishii, H. Components of the Lauraceae family-I. Tetrahedron 1972, 28, 3757-3766. [CrossRef]

20. Juan, C.; Martinez, V.; Yoshida, M.; Gottlieb, O.R. $\omega$-Ethyl, $\omega$-ethenyl and $\omega$-ethynyl- $\alpha$-alkylidene- $\gamma$-lactones from Clinostemon mahuba. Phytochemistry 1981, 20, 459-464. [CrossRef]

21. Cheng, H.I.; Lin, W.Y.; Duh, C.Y.; Lee, K.H.; Tsai, I.L.; Chen, I.S. New cytotoxic butanolides from Litsea acutivena. J. Nat. Prod. 2001, 64, 1502-1505. [CrossRef]

22. Harcken, C.; Brückner, R. Stereopure 1,3-butadiene-2-carboxylates and their conversion into non-racemic $\alpha$-alkylidenebutyrolactone natural products by asymmetric dihydroxylation. Tetrahedron Lett. 2001, 42, 3967-3971. [CrossRef] 
23. Kwon, H.C.; Baek, N.I.; Choi, S.U.; Lee, K.R. New cytotoxic butanolides from Lindera obtusiloba Blume. Chem. Pharm. Bull. 2000, 48, 614-616. [CrossRef] [PubMed]

24. Tsai, I.L.; Hung, C.H.; Duh, C.Y.; Chen, J.H.; Lin, W.Y.; Chen, I.S. Cytotoxic butanolides from the stem bark of Formosan Lindera communis. Planta Medica 2001, 67, 865-867. [CrossRef] [PubMed]

25. Seki, K.; Sasaki, T.; Wano, S.; Haga, K.; Kaneko, R. Linderanolides and isolinderanolides, ten butanolides from Lindera glauca. Phytochemistry 1995, 40, 1175-1181. [CrossRef]

26. Wang, H.D.; Chen, C.Y.; Wu, P.F. Isophilippinolide A arrests cell cycle progression and induces apoptosis for anticancer inhibitory agents in human melanoma cells. J. Agric. Food Chem. 2014, 62, 1057-1065. [CrossRef] [PubMed]

27. Chen, C.Y.; Chen, C.H.; Wong, C.H.; Liu, Y.; Lin, Y.S.; Wang, Y.D.; Hsui, Y.R. Cytotoxic constituents of the stems of Cinnamomum subavenium. J. Nat. Prod. 2007, 70, 103-106. [CrossRef] [PubMed]

28. Chia, Y.C.; Yeh, H.C.; Yeh, Y.T.; Chen, C.Y. Chemical constituents from the leaves of Cinnamomum reticulatum. Chem. Nat. Compd. 2011, 47, 220-222. [CrossRef]

29. Chen, C.Y.; Hong, Z.L.; Yang, W.L.; Wu, M.H.; Huang, J.C.; Lee, J.Y. A novel homosesquiterpenoid from the stems of Cinnamomum burmanii. Nat. Prod. Res. 2012, 26, 1218-1223. [CrossRef]

30. Mukherjee, R.K.; Fujimoto, Y.; Kakinuma, K. 1-( $\omega$-Hydroxyfattyacyl)glycerols and two flavanols from Cinnamomum camphora. Phytochemistry 1994, 37, 1641-1643. [CrossRef]

31. Kim, N.C.; Graf, T.; Sparacino, C.M.; Wani, M.C.; Wall, M.E. Complete isolation and characterization of silybins and isosilybins from milk thistle (Silybum marianum). Org. Biomol. Chem. 2003, 1, 1684. [CrossRef]

32. Puripattanavong, J.; Weber, S.; Brecht, V.; Frahm, A.W. Phytochemical investigation of Aglaia andamanica. Planta Medica 2000, 66, 740-745. [CrossRef]

33. Hsiao, P.Y.; Lee, S.J.; Chen, I.S.; Hsu, H.Y.; Chang, H.S. Cytotoxic cardenolides and sesquiterpenoids from the fruits of Reevesia formosana. Phytochemistry 2016, 130, 282-290. [CrossRef]

34. Kitagawa, S.; Nishibe, S.; Benecke, R.; Thieme, H. Phenolic compounds from Forsythia leaves. II. Chem. Pharm. Bull. 1988, 36, 3667-3670. [CrossRef]

35. Han, H.Y.; Liu, H.W.; Wang, N.L.; Yao, X.S. Sesquilignans and dilignans from Campylotropis hirtella (Franch.) Schindl. Nat. Prod. Res. 2008, 22, 984-989. [CrossRef] [PubMed]

36. Heymann, H.; Tezuka, Y.; Kikuchi, T.; Supriyatna, S. Constituents of Sindora sumatrana MIQ. I. Isolation and NMR spectral analysis of sesquiterpenes from the dried pods. Chem. Pharm. Bull. 1994, 42, 138-146. [CrossRef]

37. Chang, H.S.; Lin, C.H.; Hsiao, P.Y.; Peng, H.T.; Lee, S.J.; Cheng, M.J.; Chen, I.S. Bioactive composition of Reevesia formosana root and stem with cytotoxic activity potential. RSC Adv. 2017, 7, 27040-27047. [CrossRef]

38. Kamiya, K.; Watanabe, C.; Endang, H.; Umar, M.; Satake, T. Studies on the constituents of bark of Parameria laevigata Moldenke. Chem. Pharm. Bull. 2001, 49, 551-557. [CrossRef]

39. Thielitz, A.; Gollnick, H.P. Recent therapeutic developments for acne. Expert Rev. Dermatol. 2013, 8, 37-50. [CrossRef]

40. Hwang, T.L.; Li, G.L.; Lan, Y.H.; Chia, Y.C.; Hsieh, P.W.; Wu, Y.H.; Wu, Y.C. Potent inhibition of superoxide anion production in activated human neutrophils by isopedicin, a bioactive component of the Chinese medicinal herb Fissistigma oldhamii. Free Radic. Biol. Med. 2009, 46, 520-528. [CrossRef]

41. Hwang, T.L.; Su, Y.C.; Chang, H.L.; Leu, Y.L.; Chung, P.J.; Kuo, L.M.; Chang, Y.J. Suppression of superoxide anion and elastase release by $\mathrm{C} 18$ unsaturated fatty acids in human neutrophils. J. Lipid Res. 2009, 50, 1395-1408. [CrossRef]

Sample Availability: Samples of all compounds are available from the authors. 